\title{
The Review of Factors that Influence the Supply Chain Performance
}

\author{
Gentjan Mehmeti* \\ Bahri Musabelliu \\ Orjon Xhoxhi \\ Agricultural University of Tirana, Albania \\ *Corresponding Author; Email: gmehmeti@ubt.edu.al
}

\author{
Doi:10.5901/ajis.2016.v5n2p181
}

\begin{abstract}
This article aims to highlight the factors that influence the supply chain (SC) performance. SC performance is an aggregate of the performance of every company operating in the chain. The relationship between the companies in the SC plays a key role in the SC overall performance. There are different factors that may influence directly a company's performance but indirectly they affect the entire chain. Some of these factors are: longevity of the relationship, supply base reduction, supplier involvement, information sharing, cross-functional teams, trust and commitment. In addition, this paper identifies several other factors that influence the SC performance, such as: environmental uncertainty, top-management support, customer focus, information technology, strategic purchasing, logistic integration and supply network structure. By knowing them, strategies can be build to overcome problems, the opportunities offered can be exploit and lastly these factors can be used to develop SC models with focus on SC performance.
\end{abstract}

Keywords: Performance, Supply Chain, Supply Chain Performance

\section{Introduction}

$\mathrm{SC}$ performance is an aggregate of the performance of every company operating in the chain. If one particular company has problems, it slows down the entire chain. Consequently, all the other companies will be affected. According to Lambert and Cooper (2000), the overall performance of the SC is a synergy of the integrated companies in the process of supply chain management (SCM). Aramyan (2007) would emphasize that SC performance is an overall performance measure that depends on the performance of the supply chain stages. There are different factors that may influence directly a company's performance but indirectly they affect the entire chain. Other factors are not linked with one company only but with the entire network. Therefore, it is very important to know and understand the factors that affect the SC performance. Based on these factors strategies can be built to overcome different problems, and these factors can be used to develop SC models with focus on SC performance.

\section{The Relationship between Chain Members and Supply Chain Performance}

The SC networks are composed of interdependent relationship developed with the goal of deriving mutual benefits (Chen and Paulraj, 2004). These relationships are based on the theory of strategic management, which stresses the "collaborative advantage" (Kanter, 1994) as opposed to "competitive advantage". The relationship aspect is critically important to the effective management of the SC. As a result, the relationship between the companies in the SC plays a key role in the SC overall performance. The concept of SCM and the relationship between the members in the SC were more adversarial than cooperative. As a result, the production costs were high, the product development cycle was long, order fulfilment was long, transportation costs were high, etc. After manufactures realized the benefits of the cooperative relationship, their performance increased. Consequently, this gave a bigger boost to the performance of the entire SC more than just the sum of the increased performance of the individual members. According to Lambert and Cooper (2000), the overall performance of the SC is a synergy of the integrated companies in the process of SCM. Based on the literature of SCM, the relationships between the members of the SC incorporate some key aspects that have an influence on SC performance, which are:

- Longevity of the relationship (i.e. long-term or short-term) 
- Supply base reduction

- Supplier involvement

- Information sharing

- Cross-functional teams

- Trust and Commitment

\subsection{Longevity of the relationship and performance implications}

Suppliers contracts have increasingly become long-term, buyer-supplier are creating strategic alliances. Consequently, the overall performance of the SC has increased. One way to explain this is by implementing the transaction cost theory (Williamson, 1979). The transaction cost emerges from the assumption of opportunism behaviour and bounded rationality (Williamson, 1975). According to Williamson (1975), some economic agents are rational by intention, but subject to shortcomings that influence their decisions. Due to these shortcomings, some economic agents will pursue opportunistic behaviour like stealing, lying, cheating, distorting, misleading, etc (Williamson 1975 and 1979). In the case of short-term relationship, the supplier has incentives to engage in opportunistic behaviour since it can achieve short-term benefits. Burt and Collins (2006) argue that in the long-term relationship or strategic alliances both the supplier and buyer have made specific investment in their relationship. In this case none of the party engaged in the relationship do not have incentives to pursue opportunistic behaviour because the short-term benefits of these behaviours, are smaller than the net present value of the benefits generated by the long-term relationship. As a result, the SC performances increase in terms of product quality, cost reduction, etc. Some other benefits of the long term-relationship that influence the SC performance are:

- Increased intensity of buyer-supplier coordination (De Toni and Nassimbeni, 1999).

- According to Kotable et al (2003), suppliers will become part of a well-managed chain, through long-term relationships and will have a long lasting effect on the competitiveness of the entire chain.

\subsection{Supply base reduction and performance implication}

According to Newman (1988), the contemporary buyer - supplier relationship has shifted from contracting a large number of suppliers to the use of fewer qualified/certified suppliers. This shift has multiple benefits in terms of SC performance (Chen and Paulraj, 2004b):

- Reduced inventory management cost

- Increased economies of scale based on order volume

- Reduced time of order fulfilment due to dedicated capacity

- Work-in-process inventory from suppliers, and

- Volume consolidation and quantity discount

The two words that best summarises the above benefits are increased efficiency and reduced cost of the SC.

\subsection{Supplier involvement and performance implications}

The practice of involving the supplier to the product development process, according to Burton (1988), is attributed to the fact that supplier's accounts for $80 \%$ of product lead time problems and $30 \%$ of quality problems. Some of the benefits of involving the supplier in the product development process to the SC performance are (Cuthil et al, 1997):

- Reduced time of product development

- Increased product quality, and

- Cost reduction

\subsection{Information sharing and performance implications}

Information sharing changes the way the SC is managed and these changes may lead to, among other things, lower inventories (Simchi-Levi et al, 2003). According to Simchi-Levi et al (2003), one can design and operate the SC much more effectively and efficiently by effectively use of information available in the SC. One of the benefits of sharing information in the SC is the reduction of the so-called bullwhip effect. First, it is important to explain the bullwhip effect 
than understand the role of information sharing in reducing it. Simchi-Levi et al (2003) describe the bullwhip effect as the increased variability in orders placed as we travel up in the SC. This means that even if the customers demand for specific product does not fluctuate much, inventory and back-order levels fluctuate significantly across the SC.

\subsection{Cross-functional teams, trust \& commitment and performance implications}

SCM encompasses a wide range of activities because of this; expertise is required from various functions (Chen and Paulraj, 2004). According to Ellram and Pearson (1993) cross-functional teams contribute to cost reduction, supplier selection, improved communication, product design and total quality initiatives. As a result, SC performance should improve with the increase use of cross-functional teams. Trust and commitment is a factor that does not have a direct impact on SC performance. However, cooperation relationships arise directly from trust and commitment (Morgan and Hunt 1994). Without these two key elements, the relationship between SC members will be inefficient in the best case and will cease to exist at worst case. In a situation where trust and commitment misses in the relationship, both of the parties will have initiatives to engage in opportunistic behaviour (Williamson, 1975 and 1979). As a result, the SC performance should decrease.

\section{Other Factors that Affect Supply Chain Performance}

In the SCM literature exist other factor that influences the SC performance. Some of them are:

- Environmental uncertainty

- Top-management support

- Customer focus

- Information Technology (IT)

- Strategic Purchasing

- Logistic integration

- Supply network structure

\subsection{Environmental uncertainty}

Chen and Paulraj (2004b) consider in their study three different sources of environmental uncertainty that plague supply chains: demand uncertainty, supply uncertainty and technological uncertainty. Demand uncertainty has to do with the fluctuation in demand (e.g. customer demand, orders placed by retailers, etc). Supply uncertainty includes indicators of timeliness, supplied product quality, etc. Technological uncertainty measures the extent of technological changes over time. From the above discussion of the bullwhip effect, we can link the demand uncertainty with the bullwhip effect. The higher the demand uncertainty is the higher the fluctuation should be. As a result, the bullwhip effect should be bigger. From this simple explanation, the author deducts that the environmental uncertainty is linked in a negative way with the SC performance. When it increases the SC performance should decrease.

\subsection{Top-management support}

By top-level managers support the authors means all the activities of the top-managers to implement the philosophy of SCM in the company like: contribution to strategic purchasing, adoption of advance information technology, logistic integration, supplier relationship development, etc. Day and Lord (1988) found that top-level managers have a considerable impact on company performance. In the introduction part of this paper the author mentioned that the SC performance is an aggregate of every entity operating in the chain. Each of this entities performance is an independent variable of their top managers leading skills and abilities. By linking Day and Lord (1988) findings with this statement, it can be deduced that top-management support has a positive relationship with SC performance. Increase level of top management support should lead to increase SC performance.

\subsection{Customer focus}

It is a well know fact that satisfying customers' needs is key element in a company success. In order to understand the customers' needs a company must research its customer base. The more it focuses on the customers, the more 
rewarding the exchange transaction in the SC will be for that company (Carson et al 1998). The same concept can be applied to the SC, considering the SC as a big entity composed by different companies localised in different levels of the chain. If the entire chain is customer focused, it will better understand the customers' needs. This will lead to improved customer satisfaction (Mentzer, 2001). In terms of performance, customer satisfaction can be used as metric for measuring SC performance (Mentzer, 2001). Thus, when customer focus increases the customer satisfaction should rise, as result SC performance increases as well.

\subsection{Information Technology (IT)}

Information is vital for every SC to function properly. Implementation of the IT systems in managing the SC has impacted not only the evolution of the SCM but also the SC performance. Information technology enhances SC performance by providing real time information regarding inventory level, production requirement, product availability, and shipment status (Salcedo and Grackin, 2000).

\subsection{Strategic Purchasing}

To understand the role of strategic purchasing in the context of SC performance, its evolution must be considered first. Mentezer (2001) argues in his book about the changing role of purchasing in firms SC management. He presents a framework of the evolution stages of purchasing. According Mentezer (2001) purchasing has gone through four evolution stages, which are:

- Traditional

- Partnership/Relational

- Operation approach (Materials Logistic Management)

- Strategic approach/ Strategic purchasing (Integrated value Added

It is not the aim of this literature review to examine the evolution of the role of purchasing but by looking at these, the way strategic purchasing impacts SC performance can be better understood. The focus of traditional purchasing was to buy from the supplier that offered the lowest price; the relationship between buyer-supplier was mainly short-term (Giunipero and Brand, 1996). On the other hand, Giunipero and Brand, (1996) argues that strategic purchasing focuses on joint product innovation for competitive advantages in meeting customers demand, reducing system cycle time and cost by joint process design. Consequently, SC performance is related positively with strategic purchasing. The more the companies in the chain are focused on strategic purchasing the higher the SC performance should be. One more thing that should be noted in the context of purchasing evolution is that, the relationship longevity buyer-supplier has shifted from short-term relations (Traditional) to long-term relations (Strategic).

\subsection{Logistic Integration}

As it has been discussed in the previous parts of this literature review the relationship among the members in the SC has shifted toward strategic alliance, as a result logistic integration has extended outside the boundaries of the individual firm (Chen and Paulraj, 2004b). According to Stock et al (2000) higher levels of integration are characterized by greater coordination of the focal company's logistics activities with those of its customer and supplier, increased logistic related communication, and less clean distinction between the logistic activities of the firm and those of its customer and supplier. This increased level of logistic integration has led to greater SC performance.

\subsection{Supply network Structure}

Supply network structure has to do with the governance type of buyer-supplier relationships. As discussed in the previous part of this paper, when the buyer and supplier start/or are in a relationship there is the chance that they may engage in opportunistic behaviour. This opportunistic behaviour reduces the benefits of the party that is suffering it. Collins and Burt (2003), show some instruments to protect from opportunistic behaviour, which are monitoring, incentives, selection, and socialization. Each of these instruments varies in terms of effectiveness and implementation cost. As the cost to protect the benefits increase, the appropriate governance mode evolves from market contracting, through relational exchange, to hierarchy (Collins and Burt, 2006). Each of these types of governance has different outcomes in terms of SC performance. Thorelli (1986) suggests that network structure (relational exchange) is the best governance type, since in 
this type of governance there is a lack of power influence among the members of the supply chain. This is personified in terms of interdependence and strong linkages between SC members.

\section{Conclusions}

This article reviewed the factors that affect SC performance and the way they affect it. The factor mentioned were: Longevity of the relationship, Supply base Reduction, Supplier involvement, Information sharing, Cross-functional teams, Trust and Commitment, Environmental uncertainty, Top-management support, Customer focus, Information Technology (IT), Strategic Purchasing, Logistic integration, and Supply network structure. It should be noted that some of these factors are interrelated with each other. It can be said that SC performance is a function of the factors mentioned above. Where the SCM is the dependent variable and the factors that influence it are the independent variables. A possible option for future research would be to quantify in a regression model the relationship between the factors identified here and SC performance.

\section{References}

Burt, S.L. and Collins, A., (2006). "Private Brands, Governance, and Relational Exchange within Retailer-Manufacturer Relationship: Evidence from Irish Food Manufacturers Supplying the Irish and British Grocery Markets." Agribusiness, 22 (1): 1-20.

Burton, T.T. (1988). "JIT/repetitive sourcing strategies: trying the knot with your suppliers." Production and Inventory Management Journal, 29 (4): 38-41.

Carson, D., Gilmore, A. and Maclaran, P., (1998). "Customer or profit focus: an alternative perspective." Journal of Marketing Practice: Applied Marketing Science, 4 (1), 26-39.

Chen, I.J. and Paulraj, A., (2004). "Understanding supply chain management: critical research and a theoretical framework." International Journal of Production Research 42 (1): 131-163.

Chen, I.J. and Paulraj, A., (2004b). "Towards a theory of supply chain management: the constructs and measurements." Journal of Operation Management, 22: 119-150.

Cuthill, I.D.H., Gupta, A. and Wilemon, D., (1997). "Supplier involvement in new product development." Innovation in Technology Management - The Key to Global Leadership. PICMET '97: Portland International Conference on Management and Technology.

Day, D.V. and Lord, R.G. (1988). "Executive leadership and organizational performance: Suggestions for a new theory and methodology. Journal of Management, 14 (3): 453-464.

De Toni, A. and Nassimbeni, G., (1999). "Buyer-supplier operational practices, sourcing policies and plant performance: result of an empirical research." International Journal of Production Research, 37 (3), 597-619.

Ellram, L. M. and Pearson, J. N., (1993). "The role of the purchasing function: toward team participation." International Journal of Purchasing and Materials Management, 29: 3-9.

Giunipero, L. and Brand, R., (1996). "Purchasing role in supply chain management." The International Journal of Logistic Management, 7(1): $29-38$

Kanter, R.M. (1994). "Collaborative advantage: the art of alliances." Harvard Business Review, (July-August): 96-108.

Kotabe, M., Martin, X. and Domoto, H., (2003). "Gaining from vertical partnerships: knowledge transfer, relationship duration, and supplier performance improvement in the U.S. and Japanese automotive industries." Strategic Management Journal, 24: 293 316.

Lambert, D. M. and Cooper, M.C., (2000). "Issues in Supply Chain Management." Industrial Marketing Management, 29 (1): 65-83.

Lusine H. Aramyan, (2007). "Measuring supply chain performace in agri-food sector", PhD-thesis Wageningen University, Wageningen.

Mentezer, J.T. (2001). Supply Chain Management, Sage Publications, London.

Morgan, R. and Hunt, S., (1994). "The commitment-trust theory of relationship marketing." Journal of Marketing. 58 (Summer): 20-38.

Newman, R. G. (1988). "Single source qualification." Journal of Purchasing and Materials Management, 24: 10-17.

Salcedo, S. and Grackin, A. (2000). "The e-value chain." Supply Chain Management Review, 3 (4): 63-70.

Simchi-Levi, D., Kaminsky, P. and Simchi-Levi, E. (2003). Designing and managing the supply chain: concepts, strategies, and case studies, McGraw-Hill//rwin, Boston, 2nd edition.

Stock, G.N., Greis, N.P. and Kasarda, J.D. (2000). "Enterprise logistics and supply chain structure: the role of fit." Journal of Operations Management, 18 (5): 531-547.

Thorelli, H. (1986). "Networks: between markets and hierarchies." Strategic Management Journal, 7 (1): 37-51.

Williamson, O. E. (1975). "Markets and Hierarchies: Analysis and Antitrust Implications: A Study in the Economics of Internal Organization." University of Illinois at Urban -Champaign's Academy for Entrepreneurial Leadership Historical Research Reference in Entrepreneurship.

Williamson, O. E., (1979). "Transaction Cost economics: The governance of contractual relations." Journal of Law and Economics, 22 (2): 233-261. 
